\title{
Peculiar Characteristics of Fragmentation of Glaciers: A Case Study of Western Himalaya, India
}

\author{
Rupal M. Brahmbhatt1', B. P. Rathore², Sandhyarani Pattnaik ${ }^{2}$, Purnesh Jani ${ }^{3}$, \\ I. Bahuguna'2, R. D. Shah', A. S. Rajawat ${ }^{2}$ \\ ${ }^{1}$ M.G. Science Institute, Ahmedabad, India \\ ${ }^{2}$ Space Applications Centre, ISRO, Ahmedabad, India \\ ${ }^{3}$ Cept University, Ahmedabad, India \\ Email: rupal.brahmbhatt@gmail.com
}

Received 12 February 2015; accepted 14 April 2015; published 21 April 2015

Copyright (C) 2015 by authors and Scientific Research Publishing Inc.

This work is licensed under the Creative Commons Attribution International License (CC BY).

http://creativecommons.org/licenses/by/4.0/

(c) (i) Open Access

\section{Abstract}

The areal extent of many Himalayan glaciers is decreasing where number of glaciers is increasing. This increasing number is subject to the fragmentation of limbs of main trunk glacier. However, disintegration of limbs is not observed in all the glacier system. This paper emphases the scenario of the fragmentation occurred in glaciers. Two glaciers from the two different basins have been taken into the consideration for this study. The peculiar characteristic of these glaciers is that, the tributary glaciers are showing less retreat in compare to main trunk glaciers. Due to this reason the rate of shift in snout is higher in main trunk glaciers than tributary glaciers. However, in recent data the tributary glaciers have experienced little higher loss in glacial ice than main glacier. But the shift of snout in main trunk glacier is no doubt surprising since past. Therefore, various parameters have been examined to identify the cause of such a behavior of glaciers. The common factors observed in both the glaciers are accumulation area ratio which is higher, snow line altitude which is lower in tributary glaciers for the period of 2005-2013. Another factor is the orientation as tributary glaciers are towards NE direction. In addition, slope of Dharlang glacier (main limb) is $4^{\circ}$ where it is $18^{\circ}$ in tributary glacier.

\section{Keywords}

Fragmentation, Detachment, Glacier Retreat, Himachal Pradesh 


\section{Introduction}

Snow and glaciers are the natural reservoir of the fresh water in frozen state. The world's climate is continuously changing, with apparently random fluctuations from year to year superimposed on long period trends: such changes are reflected in variation in the extent of glaciers therefore snow and glaciers are known to be sensitive indicator of climate change. The glacier deposits such as lakes, moraines generated by glacier retreat/advances preserve record of past climate thus, important to understand paleoclimate [1]. During the peak of the glaciation, the area covered by the glaciers was 46 million sq $\mathrm{km}$ which was more than three times of the present glacier cover on the earth surface [2]. At present the total ice covered region is $14.9 \mathrm{sq} \mathrm{km}$ out of which 12.5 million sq $\mathrm{km}$ is in southern polar region and 1.7 million sq $\mathrm{km}$ is covered by Greenland ice sheet [3]. The remained 0.7 million sq km is distributed in rest of the places on earth such as Himalayan region, Andes, Alps, etc. [4]. Glaciers in Himalayas are distributed from west to east in the mountains of Pakistan, Kashmir Himachal Pradesh, Uttaranchal, Nepal, Sikkim, Bhutan and Arunachal Pradesh. Concentration of glaciers in Himalaya varies from northwest to northeast according to the variation in altitude and latitude of the region. The required atmospheric conditions for snow fall are met at higher latitudes and altitudes of the geographical locations and therefore it governs the distribution of glaciers on the earth. The mountain ranges, located at mid latitude such as Himalaya, Alps, Rocky Mountains, Cascade Range, Southern Andes as well as tropical summits such as Mount Kilimanjaro in Africa, are showing some of the largest loss of glacial ice. Regarding glaciation and deglaciation, most glaciers retreated rapidly between about 1865 and 1880, and then began a readvance which culminated shortly before 1900 [5]. The rise in temperature due to anthropogenic activity and increase in concentration of carbon dioxide [6] might be the driving force in controlling the abnormal behavior of glaciers. The field studies have revealed retreat in limited number of glaciers [7]-[9]; the remote sensing approach has been a major source of monitoring large number of glaciers located in the remote and rugged terrains in the abode of Himalaya [10][15]. Recently, the mass balance was estimated for the last decade by using SRTM and Spot-5 derived DEMs for the various climatic zones of Himalaya, which shows that loss of mass was higher in western Himalaya in comparison to the eastern and central Himalaya [16]. Moreover, glacier ice loss was estimated maximum in Jammu-Kashmir region for the $21^{\text {st }}$ century [17]. A study on mass changes using altimeter was carried out for glaciers of Pamir-Karakoram Himalaya region where they observed negative mass balance for the glaciers in Ganges, Indus and Brahmputra basins, about 10\% of the current glacier contribution to sea-level rise [18].

In the initial phase the thrust has been on finding the amount of retreat in different glaciated basins. Now with the availability of a large amount of digital database on the quantitative assessment of retreat, it is possible to compare the phenomena of retreat under different conditions of climate and morpho-glaciological setup in a specific basin.

The retreat or advance of the glaciers depends on the mass balance of the glaciers as glaciers adjust to a change in its mass balance and the first effect of change will appear at the terminus area. Due to this deglaciation of the glaciers, the losses in area, thinning of the glaciers, and fragmentation of tributary glaciers from the main glacier are observed. Thus, the number of glaciers increases unlike an area of glaciers. Generally, it has been observed that the tributary glaciers retreat faster as it is smaller in size than main glacier. In this study certain observation was made that tributary glaciers haven't experienced much deglaciation unlike the main glacier. Thus, considering quite abnormal behavior of these glaciers, further investigation has been carried out using various parameters like slope, accumulation area ratio, moraine cover, aspect of the glaciers have been studied.

\section{Study Area}

Two glaciers have been identified in the Chenab basin (Jammu and Kashmir region) for this study. This area comes in Pir - Panjal range. The glacier located in North West part of the basin, namely Bairpal Nai glacier is having $75^{\circ} 56^{\prime}-76^{\circ} 02^{\prime} \mathrm{E}$ longitude and $33^{\circ} 40^{\prime}-33^{\circ} 42^{\prime} \mathrm{N}$ latitude. Dharlang glacier is having $76^{\circ} 36^{\prime}-76^{\circ} 41^{\prime} \mathrm{E}$ longitudes and $33^{\circ} 10^{\prime}-33^{\circ} 19^{\prime} \mathrm{N}$ latitudes (Figure 1). Geologically, these glaciers are part of central crystalline zone of the Himalaya. The location map of these two glaciers is given in Figure 1.

\section{Data}

(i) For comparison of areal extents occupied by glaciers for various time frames the following sources of information were used. 


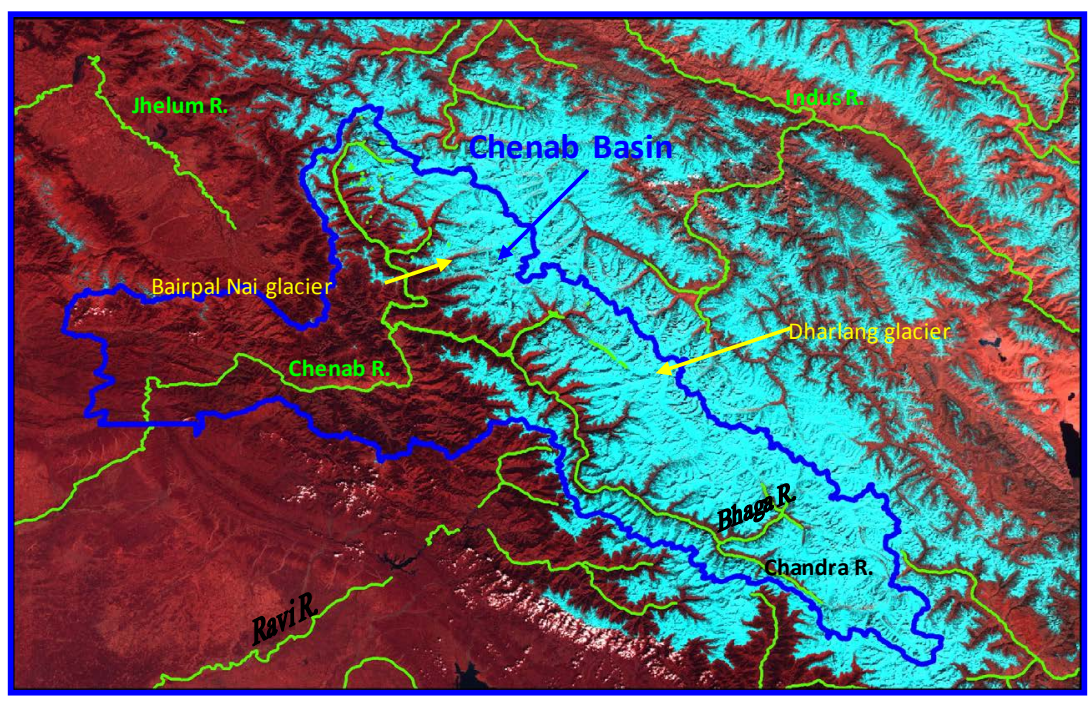

Figure 1. Location map of the study area.

(a) Survey of India topographical maps (of 1:50,000 scale) surveyed in 1962 and published in 1963 were used for generating baseline layer of glacier extents. SOI maps are normally prepared using aerial photographs with limited field investigations.

(b) Maximum extent (ME) was derived using LISS III data of 2002. By mapping and adding deglaciated valley ME was calculated.

(c) Digital images of LISS III (Linear imaging self-scanner sensor) sensor onboard IRS (Indian Remote sensing) satellite with spatial resolution of $23.5 \mathrm{~m}$ acquired on 2002, 2007, and 2011.

(ii) For estimation of AAR weakly AWiFS (advanced wide field sensor) images with spatial resolution of 56 $\mathrm{m}$ acquired in 2005 to 2013 were used.

(iii) SRTM DEM (The Shuttle Radar Topography Mission digital elevation model), provides a global coverage of earth's land surface with $90 \mathrm{~m}$ spatial resolution and $15 \mathrm{~m}$ vertical accuracy was used.

\section{Approach}

The base layer of these glaciers was delineated using SOI topographical maps (1:50,000 scale). Initially satellite data was georeferenced with topographic maps of survey of India. For geocorrections common ground control points were identified on topographic maps and satellite imageries. Then, satellite data was registered with topographic maps using polynomial model. This was produced image to map registration with sub pixel accuracy. Remaining satellite data was registered using previously geocorrected satellite images. Delineation of glacier boundary was done using band combination 2 (0.52 - $0.59 \mathrm{~m}), 3(0.62-0.68 \mathrm{~m}), 4(0.77-0.86 \mathrm{~m})$ and various enhancement techniques. SWIR band is used to discriminate the cloud and snow because the clouds are observed on the upper boundary, near the ridge of the glaciers. The understanding of reflectance curve of various glacier features helps to vectorize the glacial boundary on satellite data. The terminus is identified using multiple criterions for example: 1) Sometimes the river originates from the snout; 2) The periglacier area downstream of the snout has distinct geomorphological set up then the glacier surface; 3) In many instances the frontal portion of the glaciers, which are retreating has convex shape; 4) When interpretation becomes more complex sometimes DEM is used in the background to confirm the snout as there is a chance of change in the slope of glacier profile near the snout and $3 \mathrm{~d}$ view help to identify the lateral and terminal boundary of glacial extent. Extreme care is taken while delineating glacier boundary that whether it was marked in the inner side of the lateral moraines.

The accumulation area ratio was taken from the results published by Brahmbhatt, et al. 2012. After 2007, the snow line altitude and AAR was derived using AWiFS and SRTM data. Debris cover on the glaciers has been mapped using visual interpretation and various enhancement techniques. Especially, band combination 2 (0.52 $0.59 \mathrm{~m}), 4(0.77-0.86 \mathrm{~m})$ and $5(1.55-1.75 \mathrm{~m})$ was used for estimation of debris cover. To measure the slope of glacier highest and lowest elevation was taken from SRTM data. Slope has been estimated for fragmented glaci- 
ers and main glaciers. Area altitude distribution of glaciated region was generated using contour map extracted from DEM available from SRTM (Shuttle Radar Topography Mission). The interval of contours was taken as $300 \mathrm{~m}$. Glacier boundaries are overlaid on the elevation zones in a GIS environment and based on intersection of two layers the area of glaciers is estimated for each elevation zone.

\section{Uncertainty of Results}

The uncertainty of mapping and change in area was measured using well established equation [19] [20].

The mapping error was estimated using following equation:

$$
\text { Mapping Uncertainity }=N \times \frac{A}{2}
$$

where, $N=$ is the number of pixels along the glacier boundary, and $A$ is the area of the pixel.

The uncertainty in glacier area change was measured using following equation:

$$
\text { Uncertainity in glacier change }=N s \times A
$$

where, $N_{S}$ is the number of pixels along the boundary of the snout where changes occurred, and $A$ is the area of the pixel.

\section{Result and Discussion}

Generally, it has been found that the tributary glaciers are retreating and get detached from the main trunk glacier. In our study, two glaciers located in Chenab basin were observed to be showing strange behavior in their own glacier system. The rate of retreat in main trunk glacier was higher in comparison to the tributary glacier in both the glacier system. These two glaciers are described individually in following paragraphs.

\subsection{Bairpal Nai Glacier ( $33^{\circ} 41^{\prime} 17.77^{\prime \prime N}, 75^{\circ} 58^{\prime} 07.93^{\prime E}$ )}

The maximum extent of glacier was mapped using satellite data by including deglaciated valley. In past, the main glacier had additional five limbs which were feeding to main limb. This glacier was having an area of $30.01 \mathrm{sq} \mathrm{km}$ in 1962 which has become $26.32 \mathrm{sq} \mathrm{km} 2002$ (Figure 2). The lowest altitude of the compound glacier was $3800 \mathrm{~m}$ in 1962. After the fragmentation of this glacier, the lowest altitude of main glacier was 4290 $\mathrm{m}$ and lowest altitude of the fragmented tributary glacier is $4080 \mathrm{~m}$. Out of 5 limbs three got detached from main trunk glacier during the period of 1962 and 2002. These three tributaries have experienced deglaciation at dif-

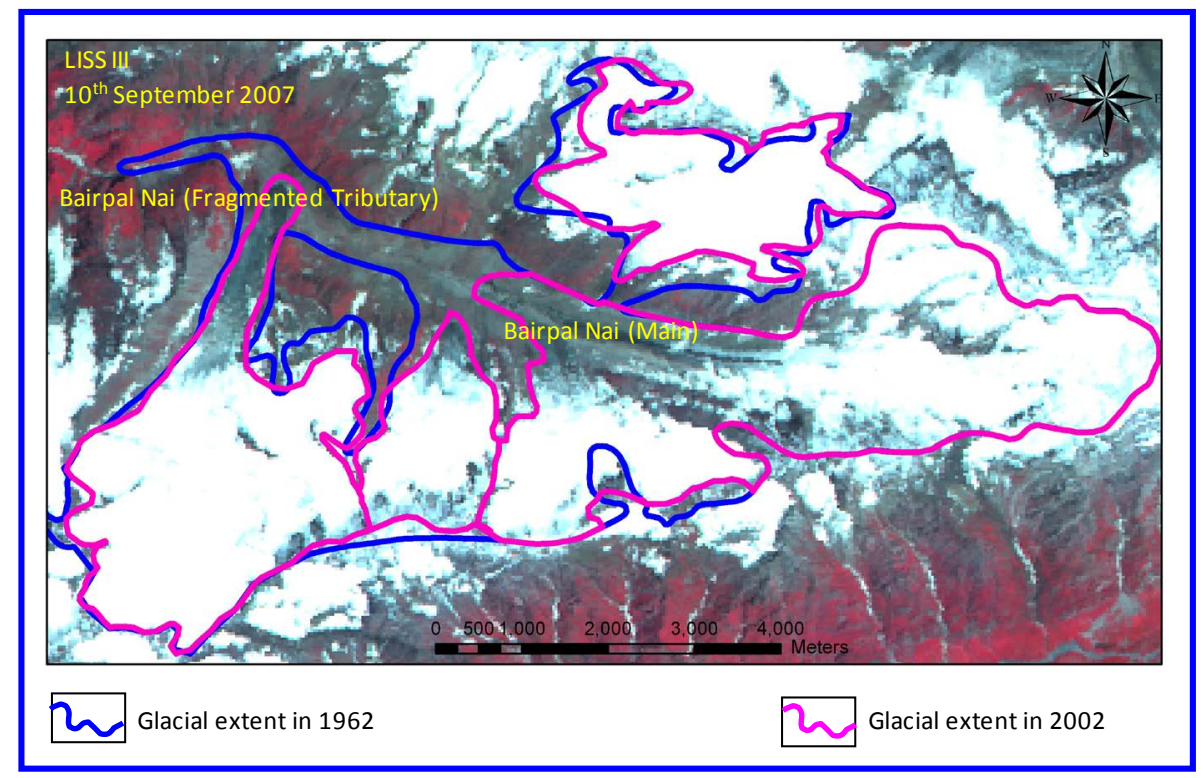

Figure 2. Bairpal Nai glacier. 
ferent rates. The peculiar thing was observed in one of the tributary glacier $\left(33^{\circ} 40^{\prime} 18.93^{\prime \prime} \mathrm{N}, 75^{\circ} 56^{\prime} 17.91^{\prime \prime} \mathrm{E}\right)$ has shown less retreat in compare to main trunk glacier. Further study was carried out only in main trunk glacier and the tributary glacier located near the snout. Besides the main limb has shown higher retreat up to 2007 (Table 1) and after 2007 fragmented tributary has shown more loss in area where snout has not shifted much. The results show that tributary glacier has experienced loss of ice laterally during the monitoring period of 2007-2011.

One unusual observation about this tributary glacier is that the snout of glacier has not shifted back from its position since past unlike the main trunk glacier. To investigate this behavior various parameters were analyzed such as area altitude of distribution, snowline altitude, accumulation area ratio. Of course, snow line altitude and AAR have been measured using recent data which has no relation with the deglaciation occurred in past but according to authors, these two parameters provide the pattern of accumulation of the two glaciers located in the same system.

While comparing the area altitude distribution of these two glaciers, the tributary glacier has more area on higher altitude. $36 \%$ area of the main trunk glaciers is located between $4500-4800 \mathrm{~m}$, where as $51 \%$ area of the tributary glacier is located between 4800 - $5100 \mathrm{~m}$ elevation zones (Figure 3). The mean equilibrium line altitude for these years has been found to be $4746 \mathrm{~m}$ and $4700 \mathrm{~m}$ for main and fragmented tributary glacier respectively. 58\% of the area was found to be located below snow line altitude in main glacier where it is just $40 \%$ in fragmented tributary glacier (Figure 4(a)). In case of accumulation area ratio of two glaciers, the mean AAR of 8 years is higher in tributary glacier which is 0.59 and 0.69 in main and fragmented glaciers respectively (Figure 4(b)). Contrary, literature suggest that the glaciers covered by debris retard melting in due course of its thickness [21]. However, in this glacier, though tributary glacier is debris free unlike main glacier, but main glacier has experience high rate of deglaciation since past.

\section{Table 1. Salient results of glaciers.}

\begin{tabular}{|c|c|c|c|c|}
\hline Various parameters & \multicolumn{2}{|c|}{ Bairpal Nai glacier (3800 m) } & \multicolumn{2}{|c|}{ Dharlang glacier (3000 m) } \\
\hline Maximum extent $\left(\mathrm{km}^{2}\right)$ & \multicolumn{2}{|c|}{$30.2 \pm 0.7$} & \multicolumn{2}{|c|}{$61.7 \pm 1.7$} \\
\hline Glacier area in $1962\left(\mathrm{~km}^{2}\right)$ & \multicolumn{2}{|c|}{$30.1 \pm 0.7$} & \multicolumn{2}{|c|}{$62.6 \pm 1.8$} \\
\hline Glacier area in $2002\left(\mathrm{~km}^{2}\right)$ & \multicolumn{2}{|c|}{$26.2 \pm 0.8$} & \multicolumn{2}{|c|}{$58.6 \pm 1.9$} \\
\hline Loss in Area (\%) (1962-2002) & \multicolumn{2}{|c|}{$12 \pm 1.6$} & \multicolumn{2}{|c|}{$6 \pm 0.5$} \\
\hline Fragmentation & \multicolumn{2}{|c|}{4} & \multicolumn{2}{|c|}{2} \\
\hline Major glaciers (main \& tributary) & Main & Fragmented & Main & Fragmented \\
\hline Glacier area in $2002\left(\mathrm{~km}^{2}\right)$ & $11.8 \pm 0.34$ & $7.6 \pm 0.23$ & $49.1 \pm 1.6$ & $8.6 \pm 0.33$ \\
\hline Glacier area in $2007\left(\mathrm{~km}^{2}\right)$ & $11.6 \pm 0.33$ & $7.5 \pm 0.19$ & $48.9 \pm 1.59$ & $8.4 \pm 0.32$ \\
\hline Loss in area (\%) (2002-2007) & $1.7 \pm 0.4$ & $1.31 \pm 0.5$ & $0.4 \pm 0.1$ & $2.3 \pm 0.4$ \\
\hline Glacier area in $2011\left(\mathrm{~km}^{2}\right)$ & $11.5 \pm 0.32$ & $7.5 \pm 0.19$ & $48.9 \pm 1.59$ & $8.4 \pm 0.32$ \\
\hline Loss in area (\%) (2007-2011) & $0.4 \pm 0.7$ & $0.8 \pm 0.2$ & 0 & 0 \\
\hline Linear change (m) (2002-2007) & 641.3 & 107.6 & 329.8 & 0 \\
\hline Linear change (m) (2007-2011) & 209.1 & 144.7 & 0 & 0 \\
\hline Mean AAR (2005 to 2013) & 0.6 & 0.7 & 0.4 & 0.6 \\
\hline Slope (degree) & 10 & 12 & 4 & 18 \\
\hline Debris (\%) & 32 & $0 \%$ & $24 \%$ & $12 \%$ \\
\hline Mean SLA (m) (2005 to 2013) & 4735 & 4725 & 5047 & 4851 \\
\hline Area below SLA (\%) & 58 & 40 & 51 & 45 \\
\hline Orientation & West & North East & West & North East \\
\hline Snout elevation (m) (2002) & 4290 & 4080 & 4200 & 4000 \\
\hline
\end{tabular}




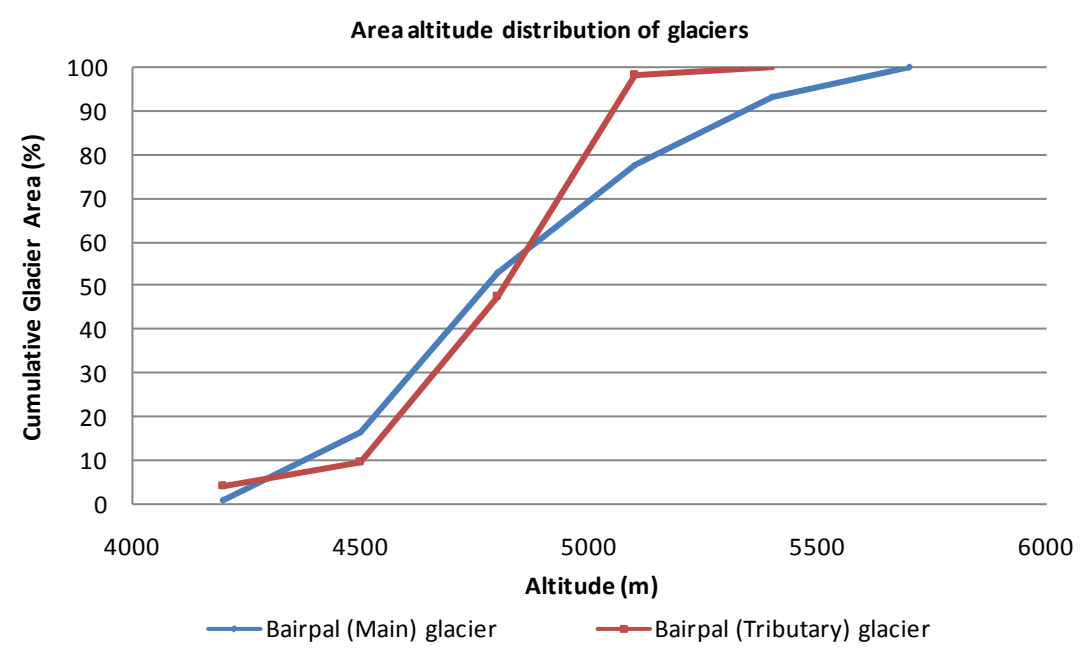

Figure 3. Area altitude distribution of the Bairpal Nai (main) glacier and Bairpal (fragmented tributary) glacier.

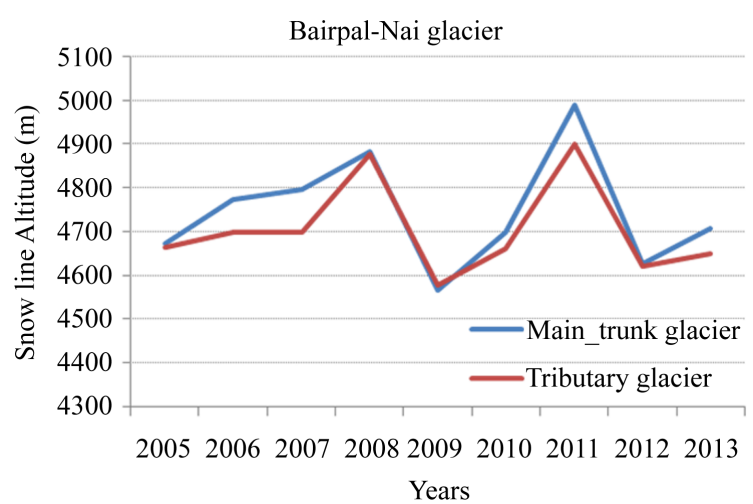

(a)

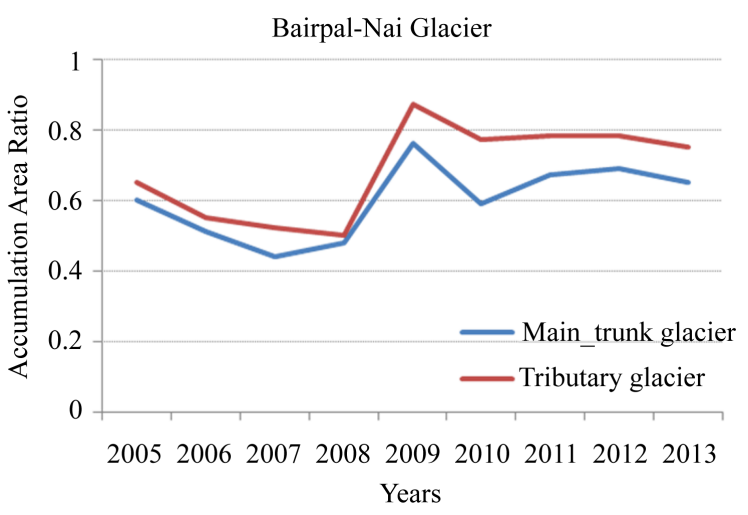

(b)

Figure 4. Variation in snow line altitude and AAR of Bairpal Nai glacier (a) snowline altitude (b) AAR of the main trunk glacier and tributary glacier.

\subsection{Dharlang Glacier ( $\left.33^{\circ} 12^{\prime} 37.14 " \mathrm{~N}, 76^{\circ} 43^{\prime} 28.56^{\prime \prime E}\right)$}

Dharlang glacier is large glacier system, it has many tributaries out of which one tributary is located near its snout thus located at lower altitude. The maximum extent of glacier was mapped using LISS III data by adding the deglaciated valley. Furthermore in 1962 as per SOI maps, it was having an area of $62.6 \mathrm{sq}$ km which has decreased to $58.6 \mathrm{sq} \mathrm{km}$ in 2002 (LISS III), shows 6\% loss in area (Figure 5). This glacier was fragmented into two glaciers due to the deglaciation during the monitoring period of 1962 and 2002. The lowest altitude of the compound glacier was $3000 \mathrm{~m}$ in 1962 . After the fragmentation of this glacier, the lowest altitude of main glacier was $4200 \mathrm{~m}$ and lowest altitude of the fragmented tributary glacier is $4000 \mathrm{~m}$. Furthermore the tributary has shown higher retreat from 2002 to 2007 (table) and after 2007 both the glaciers have not shown any change. The name of the tributary glacier is Shib-Shankar as per the SOI maps. The tributary (Shib-Shankar) of this glacier has also behaved same as the tributary of Bairpal Nai glacier. The tributary glacier has not experienced much loss in compare to the main glacier. Various parameters have been analyzed in this glacier as well. The $90 \%$ of the Dharlang (main) glacier area is located below $5400 \mathrm{~m}$ where it is $83 \%$ of Shib-Shankar (fragmented tributary) glacier (Figure 6). The mean equilibrium line altitude for eight years has been found to be $5047 \mathrm{~m}$ and $4851 \mathrm{~m}$ in main and fragmented tributary glacier respectively (Figure 7(a)). The area below snow line is $51 \%$ in main glacier and it is $45 \%$ in fragmented tributary glacier. The mean accumulation area ratio for 8 years is 0.44 and 0.51 for the main and tributary glaciers respectively (Figure 7(b)). Another parameter is the slope which is 4 degree in Dharlang and 18 in Shib-Shankar (fragmented tributary) glacier. 


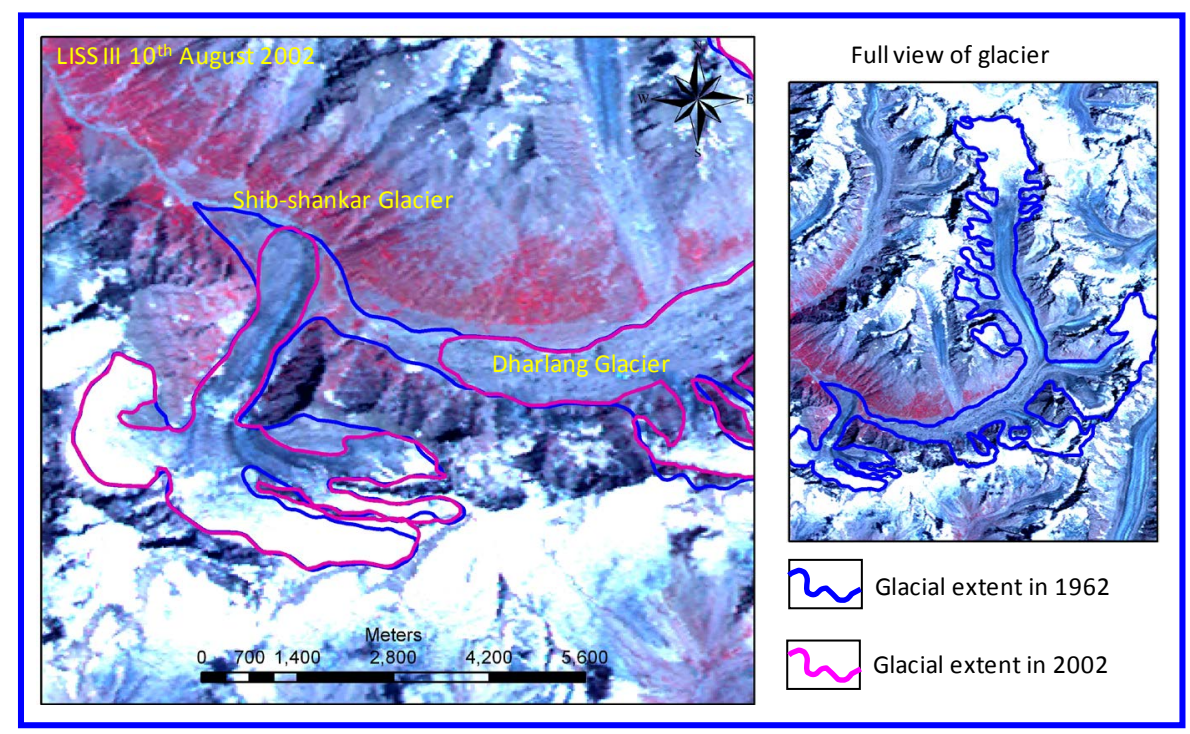

Figure 5. Dharlang (main) glacier and Shib-Shankar (fragmented tributary) glacier.

Area altitude distribution of glaciers

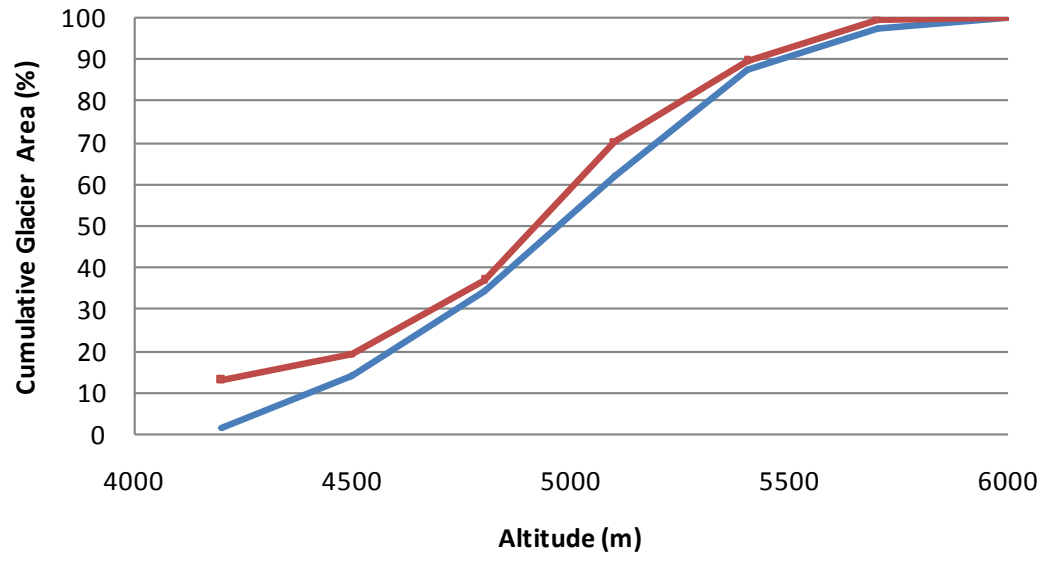

—Dharlang (Main) Glacier —Shib-shankar (Tributary) Glacier

Figure 6. Area altitude distribution of the Dharlang (main) glacier and Shib-Shankar (fragmented tributary) glacier.

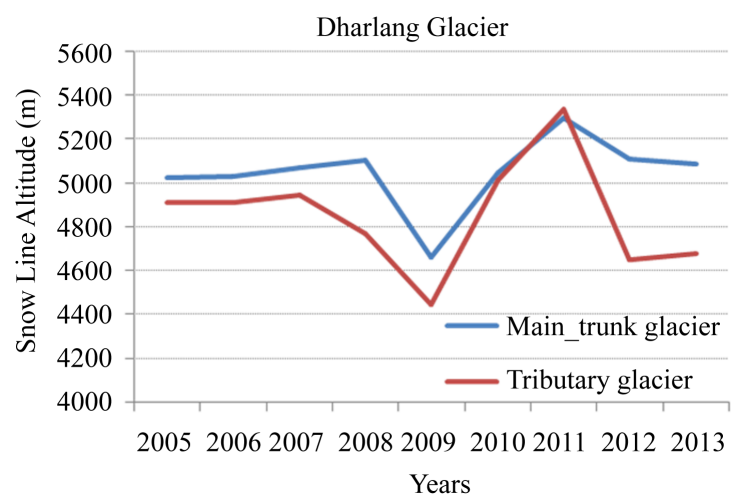

(a)

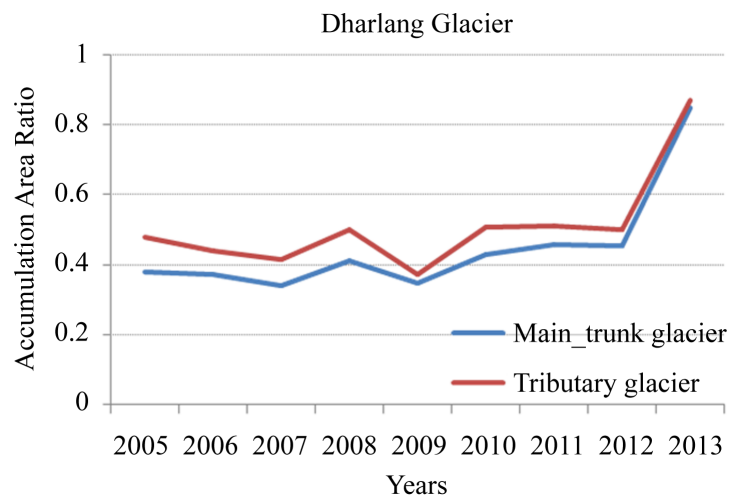

(b)

Figure 7. Variation in snow line altitude and AAR of Dharlang glacier (a) snowline altitude (b) AAR of the main trunk glacier and tributary glacier. 


\subsection{Discussion}

The peculiar characteristic of these glaciers is higher deglaciation of main trunk glacier in comparisons to tributary glacier. Due to this reason the rate of shift in snout is higher in main trunk glaciers than tributary glaciers. However, in recent data the tributary glaciers have experienced little higher loss in glacial ice than main glacier. But the shift of snout in main trunk glacier is no doubt surprising since past.

The snowline altitude was identified at lower altitude in both the tributary glaciers in comparison to their main limb. Similarly, AAR was also higher in tributary glaciers, which means that the precipitation of snow cover is more in fragmented glacier. In fact, the relation between retreat and AAR has been well established [22]. Moreover, the tributary glacier is located at higher altitude (Figure 3 and Figure 6). One more major parameter is slope, though in Bairpal Nai glacier system it is similar $10^{\circ}$ (main glacier) and $12^{\circ}$ (tributary glacier) but in Dharlang glacier it shows big difference which is $4^{\circ}$ (main glacier) and $18^{\circ}$ (tributary glacier). This is possible reason because the velocity of the glacier depends on the slope and its internal structure therefore the AAR and snow line altitude is more and low in tributary glacier respectively. One more factor which has impact on glacier change is the orientation of the glacier; it has strong relation with accumulation area ratio as well. It is well known fact that the glacier's orientation towards North will show less retreat and the glacier's orientation towards South will show more retreat due to solar inclination angle (Benn and Evans, 2010). This is observed in both the glaciers; the fragmented tributary glaciers have orientation towards North unlike main glaciers. This might be the controlling factor to face less retreat in tributaries. After looking at all geomorphic parameters, it seems that AAR, slope and altitude have played great influence on retreat of tributaries of both glaciers.

\section{References}

[1] Balco, G. (2009) The Geographic Footprint of Glacier Change. Science (Invited Perspective), 324, 599. http://dx.doi.org/10.1126/science.1172468

[2] Embleton, C. and King, C.A. (1975) Glacial Geomorphology. Edward Arnold, London, Volume I, 9-40.

[3] Flint, R.F. (1971) Glacial and Quaternary Geology. John Wiley, New York, 892 p.

[4] Sugden, D.E. and John, B.S. (1976). Glaciers and Landscapes. Edward Arnold (Publishers) Ltd., London, 376p.

[5] Cuffey, K.M. and Paterson, W.S.B. (2010) The Physics of Glaciers. Elsevier, Burlington.

[6] Thomas, R., Frederick, E., Krabill, W., Manizade, S. and Martin, C. (2009) Recent Changes in Greenland Outlet Glaciers. Journal of Glaciology, 55, 147-162. http://dx.doi.org/10.3189/002214309788608958

[7] Yamada, T., Shiraiwa, T., Iida, H., Kadota, T., Watanabe, T., Rana, B., Ageta, Y. and Fushimi, H. (1992) Fluctuations of the Glaciers from 1970s to 1989 in the Khumbu, Shorong and Langtang Regions, Nepal Himalaya. Bulletin of Glaciers Research, 10, 11-19.

[8] Naithani, A.K., Nainwal, H.C., Sati, K.K. and Prasad, C. (2001) Geomorphological Evidences of Retreat of Gangotri Glacier and Its Characteristics. Current Science, 80, 87-94.

[9] Dobhal, D.P., Gergan, J.T. and Thayyen, R.J. (2008) Mass Balance Studies of Dokriani Glacier from 1992-2000, Uttarakhand Himalaya, India. Bulletin of Glaciological Research, 25, 9-17.

[10] Schmidt, S. and Nusser, M. (2012) Changes of High Altitude Glaciers from 1969 to 2010 in the Trans-Himalayan Kang 2 Yatze Massif, Ladakh, Northwest India. Arctic, Antarctic, and Alpine Research, 44, 107-121. http://dx.doi.org/10.1657/1938-4246-44.1.107

[11] Kulkarni, A.V. and Bahuguna, I.M. (2002) Glacial Retreat in the Baspa Basin, Himalaya, Monitored with Satellite Stereo Data. Journal of Glaciology, 48, 171-172. http://dx.doi.org/10.3189/172756502781831601

[12] Brahmbhatt, R.M., Bahuguna, I.M., Rathore, B.P., Kulkarni, A.V., Nainwal, H.C., Shah, R.D. and Ajai (2012) A Comparative Study of Deglaciation in Two Neighboring Basins (Warwan and Bhut) of Western Himalaya. Current Science, 103, 298-304.

[13] Bahuguna, I.M., Rathore, B.P., Brahmbhatt, R.M., Sharma, M., Dhar, Sunil, Randhawa, S.S., Kumar, K., Rhomshoo, S., Shah, R.D., Ganjoo, R.K. and Ajai (2014) Are the Himalayan Glaciers Retreating? Current Science, 106, 10081013.

[14] Kulkarni, A.V., Bahuguna, I.M., Rathore, B.P., Singh, S.K., Randhawa, S.S., Sood, R.K. and Dhar, Sunil (2007) Glacial Retreat in Himalaya Using Remote Sensing Satellite Data. Current Science, 92, 69-74.

[15] Venkatesh, T.N., Kulkarni, A.V. and Srinivasan, J. (2012) Relative Effect of Slope and Equilibrium Line Altitude on the Retreat of Himalayan Glaciers. The Cryosphere, 6, 301-311. 
[16] Gardelle, J., Berthier, E., Arnaud, Y. and Kääb, A. (2013) Region-Wide Glacier Mass Balances over the Pamir-KarakoramHimalaya during 1999-2011. The Cryosphere, 7, 1263-1286. http://dx.doi.org/10.5194/tc-7-1263-2013

[17] Kääb, A., Berthier, E., Nuth, C., Gardelle, J. and Arnaud, Y. (2012) Contrasting Patterns of Early Twenty-First-Century Glacier Mass Change in the Himalayas. Nature, 488, 495-498. http://dx.doi.org/10.1038/nature11324

[18] Kääb, A., Nuth, C., Treichler, D. and Berthier, E. (2014) Brief Communication: Contending Estimates of Early 21st Century Glacier Mass Balance over the Pamir-Karakoram-Himalaya. The Cryosphere, 8, 5857-5874. http://dx.doi.org/10.5194/tcd-8-5857-2014

[19] Basnett, S., Kulkarni, A.V. and Bolch, T. (2013) The Influence of Debris Cover and Glacial Lakes on the Recession of Glaciers in Sikkim Himalaya, India. Journal of Glaciology, 59, 1035-1046. http://dx.doi.org/10.3189/2013JoG12J184

[20] Hall, D.K., Bahr, K.J., Shoener, W., Bindschadler, R.A. and Chien, J.Y.L. (2003) Consideration of the Errors Inherent in Mapping Historical Glacier Positions in Austria from the Ground and Space (1893-2001). Remote Sensing of Environment, 86, 566-577. http://dx.doi.org/10.1016/S0034-4257(03)00134-2

[21] Benn, D.I. and Evans, D.J.A. (2010) Glaciers and Glaciations. 2nd Edition, Arnold, London, 734 p.

[22] Brahmbhatt, R.M., Nainwal, H.C. and Kulkarni, A.V. (2014) Impact of Accumulation Area Ratio (AAR) on Glacial Change: A Few Examples of Jammu \& Kashmir. Journal of Geomatics, 8, 61-65. 